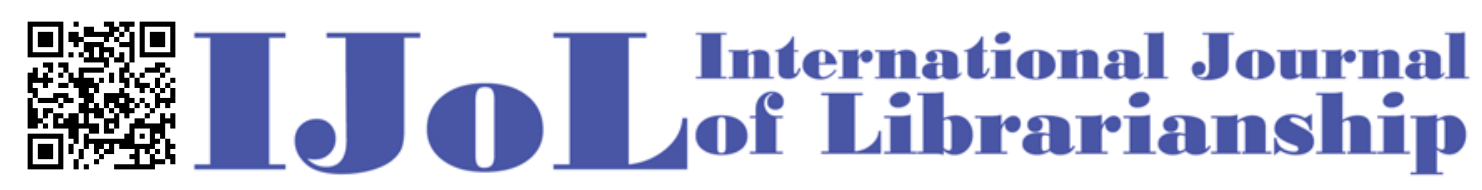

ISSN: 2474-3542 Journal homepage: http://journal.calaijol.org

\title{
ALA UN 2030 Sustainable Development Goals Task Force
}

Robin Kear and Loida Garcia-Febo

\begin{abstract}
:
This field report explores the recent planning and work underway by the American Library Association's United Nations 2030 Sustainable Development Goals Task Force.
\end{abstract}

To cite this article:

Kear, R., \& Garcia-Febo, L. (2020). ALA UN 2030 sustainable development goals task force. International Journal of Librarianship, 5(2), 94-97. https://doi.org/10.23974/ijol.2020.vol5.2.173

To submit your article to this journal:

Go to http://ojs.calaijol.org/index.php/ijol/about/submissions 
INTERNATIONAL JOURNAL OF LIBRARIANSHIP, 5(2), 94-97.

\title{
ALA UN 2030 Sustainable Development Goals Task Force
}

\author{
Robin Kear, University of Pittsburgh, Pittsburgh, PA, USA \\ Loida Garcia-Febo, International Library Consultant, USA
}

\begin{abstract}
This field report explores the recent planning and work underway by the American Library Association's United Nations 2030 Sustainable Development Goals Task Force.

Keywords: American Library Association, Sustainability, Sustainable Development Goals, and American Library Association UN SDG Task Force
\end{abstract}

\section{INTRODUCTION}

The American Library Association (ALA) United Nations 2030 Sustainable Development Goals (SDGs) Task Force (TF) was created in January of 2020 by the ALA Executive Board during its Midwinter Meeting. The TF purpose is to develop a multi-year strategic plan in the coming year to increase participation by libraries in efforts to achieve the SDGs. This is an initiative from the ALA President-elect Julius C. Jefferson Jr. for his upcoming presidential year.

The 17 Sustainable Development Goals were adopted by all the United Nations Member States during the General Assembly of September 2015. These represent a plan to guide countries worldwide in their development efforts. Thus, setting up an agenda to be accomplished by 2030 .

As per the United Nations, the Sustainable Development Goals are a "call to action to end poverty, protect the planet and improve the lives and prospects of everyone, everywhere" (United Nations, 2015a).

The International Federations of Library Associations and Institutions (IFLA) has advocated for access to information, culture, education and Information and Technology Communications (ICTs) on behalf of libraries at the United Nations since January 2014. Librarians representing IFLA and working together with civil society organizations and a global network of librarians were successful in ensuring that access to information was part of the text of Target 16.10 of Goal 16 Peace Justice and Strong Institutions. Target 16.10 reads, "ensure public access to information and protect fundamental freedoms, in accordance with national legislation and international agreements" (United Nations, 2015b).

The inclusion of "access to information" was a historical win for the library community because it is the first time the United Nations included it in a document of such nature. The Millennium Development Goals, which were the U.N. goals in place before the SDGs, did not include it. These 8 Millennium Development Goals guided the world for the previous 17 years 
on national and local levels. Progress in these goals did happen and were most effective when everyone worked together globally. The 2012 UN Sustainable Development Conference in Rio $($ Rio+20) was an important conference that considered environmental issues and worked to expand the worldwide goals to advance society. Open forums and a more democratic process was created to scope the goals; 5 million people were involved in the process. The 2030 SDGs were born to advance 5 main areas: People, Planet, Prosperity, Peace, and Partnerships. The 17 goals and 169 targets are interdependent.

IFLA has asked library associations around the world to join in a global effort to highlight how libraries contribute to the SDGs. These efforts help our libraries, our profession, and our communities. From 2016 to 2018, IFLA ran the International Advocacy Programme (IAP) as a capacity-building program designed to promote and support the role libraries can play in the planning and implementation of global goals (IFLA, 2018). Six regional workshops were held around the world with library administrators and leaders from 76 countries to build capacity for national library groups to work with their national governments. The overall goals of the workshops were to raise awareness on the UN 2030 agenda, SDGs, and the significance of public access to information in the achievement of the SDGs. The workshop trainers gave a thorough understanding of the UN2030 agenda and how to identify stakeholders in their own countries. It helped participants develop a national advocacy plan and create plans to meet with library associations, local governments, national governments, and community groups. There is a toolkit and booklet available from the IFLA website; along with templates and social media channel suggestions, such as \#Lib4Dev (IFLA, 2017).

\section{TASK FORCE ACTIVITIES}

The TF has been active amid the pandemic developing resources such as webinars and charts to help libraries understand how they are already helping communities meet the SDGs. The role of libraries in the UN 2030 is significant and ALA members and United States libraries can directly or indirectly support many of the goals and targets. Libraries also are uniquely positioned to raise awareness of the SDGs with their broad reach into communities.

To date, the TF has created two charts for use by libraries, one chart featuring how libraries are helping communities meet the United Nations Sustainable Development Goals, in general, and another one specifically showing examples of how this is done in times of COVID19. A third chart was developed by the Los Angeles Public Library featuring its programs and services and how they speak to each one of the SDGs. All charts are published on a dedicated website developed by ALA's International Relations Office (IRO) that serves as a resource site for all TF activities (ALA, 2020).

A webinar entitled "Libraries Contributing to Meet the United Nations Sustainable Development Goals: a call to action to end poverty, protect the planet and improve the lives and prospects of everyone, everywhere" was presented on June 9, 2020 by the TF. It highlighted inspiring stories from libraries in Australia, France and Germany presented by leaders of library associations in those countries. They presented the websites created to share these stories and discussed how libraries are helping communities meet the SDGs in each country. The goal was to encourage U.S. libraries to connect the dots between their existing services and the way they are already meeting the SDGs.

The event, moderated by Loida Garcia-Febo, Chair of the TF, welcomed the following guest speakers, Thanos Giannakopoulos, Director The Dag Hammarskjöld Library at the United Nations in New York; Vicki McDonald, State Librarian and Chief Executive Officer of 
the State Library of Queensland, Australian Library and Information Association President 2017-2018, and Chair of the Professional Committee at IFLA; Raphaëlle BATS, International Relations Officer of the National School of Libraries and Information Sciences (Enssib), Governing Board member of Le Comité français international bibliothèques et documentation (Cfibd); Hella Klauser, Internationale Kooperation, German Library Association, Deutscher Bibliotheksverband e.V., Kompetenznetzwerk für Bibliotheken.

Additionally, the Chair of the TF has been invited to share the group's efforts at virtual events such as the "Library 2.020 mini-conference: Sustainability in Libraries" webinar presented on October 14, 2020 by the San Jose State University School of Information and "Libraries and Sustainability - the 17 Goals in Focus for Libraries Worldwide," a webinar presented on September 24, 2020 by the German Library Association. Six members of the TF will be featured speakers at "Philippine Libraries and Their Role in the United Nations Sustainable Development Goals (SDGs)," a virtual event on November 20, 2020 highlighting the celebration of the Philippines $30^{\text {th }}$ Library and Information Services Month.

The TF is supported by the ALA's International Relations Office. The members of the Task Force work together to develop resources. They are Connie Champlain, Tina Chan, Robin Kear, Erika Long, Donna Scheeder, John Szabo, Evviva Weinraub, Daniela Sokokovic, and Shaddy Shadrach.

In the upcoming months, the TF will be tackling the development of a multi-year strategic plan. The process will include ALA members and other library associations.

In the meantime, as Garcia-Febo said, members will continue collaborating to develop resources that demonstrate how "libraries are essential to development and their services are a platform to do good in the world by adopting sustainable thinking and transforming lives through education and lifelong learning" (ALA, 2020).

Libraries facilitate access to information and can have an impact across the whole 2030 agenda. Libraries are well positioned to work across society. We promote the rights of citizens, develop relevant collections, model standards of information ethics, and give access to technology. As a national association, we need to advocate these contributions loudly and consistently to the world's development. We need to increase awareness and give clear statements of the critical contribution we can make and have clear examples of good practice and evidence to support our claims. The ALA TF can help us do that.

\section{References}

American Library Association (ALA). (2020). ALA Task Force on United Nations 2030 Sustainable Development Goals. Retrieved November 11, 2020 from http://www.ala.org/aboutala/ala-task-force-united-nations-2030-sustainabledevelopment-goals

International Federation of Library Associations and Institutions (IFLA). (2017). IFLA Toolkit: Libraries, Development and the United Nations 2030 Agenda. Retrieved November 11, 2020 from https://www.ifla.org/publications/node/10156

International Federation of Library Associations and Institutions (IFLA). (2018). The International Advocacy Programme (IAP). Retrieved November 11, 2020 from https://www.ifla.org/ldp/iap

United Nations. (2015). The Sustainable Development Agenda - United Nations Sustainable Development. Retrieved November 11, 2020 from https://www.un.org/sustainabledevelopment/development-agenda/ 
United Nations. (2015). The Sustainable Development Goals - Goal 16: Promote Just, Peaceful, and Inclusive societies. Retrieved November 11, 2020 from https://www.un.org/sustainabledevelopment/peace-justice/.

\begin{abstract}
About the authors
Robin Kear is a Liaison Librarian at the University of Pittsburgh in the USA. Robin served as an information services intern for the United Nations in Nairobi, Kenya, and has taught in Vietnam and Kazakhstan. She is currently Secretary of the IFLA Social Sciences Library Section, chairing the ALA Conference Committee and serving on the ALA Center for the Future of Libraries Advisory Group.

Loida Garcia-Febo is Puerto Rican, graduated in Business, with a Master's Degree in LIS. International Library Consultant, and President of the American Library Association, 20182019. At IFLA: Governing Board 2013-2017 and currently a member of the Management of Library Associations Section. At ALA: Chair, ALA UN 2030 Sustainable Development Goals.
\end{abstract}

